\title{
Analisis Finansial Peternakan Sapi Perah Peternak Gapoktan Sumber Mulya di Kabupaten Kepahiang Bengkulu
}

\author{
Dadang Suherman ${ }^{1}$ dan Sutriyono ${ }^{1}$ \\ ${ }^{1}$ Jurusan Peternakan Fakultas Pertanian Universitas Bengkulu \\ Jalan Raya W R.Supratman Kandang Limun Bengkulu \\ *Korespondensi : dsuherman@unib.ac.id
}

Artikel ini diterima (received): 22 April 2021; dinyatakan disetujui (accepted): 28 Mei 2021; terbit (published): 30 Mei 2021. Artikel ini dipublikasi secara daring pada https://ejournal.unib.ac.id/index.php/buletin_pt/index

\begin{abstract}
Abstrak
Penelitian ini bertujuan untuk mengevaluasi kelayakan usaha peternakan sapi perah peternak Gapoktan Sumber Mulya di Kabupaten Kepahiang Bengkulu. Penelitian ini dilaksanakan dari bulan Juli sampai dengan Agustus 2018 pada usaha peternakan sapi perah peternak Gapoktan Sumber Mulya di Kabupaten Kepahiang Bengkulu. Metode penelitian menggunakan studi kasus. Data dikumpulkan kemudian ditabulasi dan dianalisis menggunakan analisis finansial dengan kriteria (Return On Invesment, Payback Period, Net Present Value, Benefit Cost Ratio, dan Internal Rate of Return). Hasil penelitian menunjukkan bahwa Return On Invesment $(22,82 \%)$ lebih tinggi daripada tingkat suku bunga deposito (9 \%). Jangka waktu pengembalian Payback Period (4 tahun 5 bulan) merupakan hasil periode lebih maksimum yang diperkirakan usaha (10 tahun), Net Present Value (Rp. 25.421.240,00), dan Benefit Cost Ratio $(1,45)$ mempunyai nilai positif dan nilai lebih tinggi (daripada 1), perkiraan nilai Internal Rate of Return $(28,45 \%$ ) adalah lebih tinggi daripada tingkat suku bunga kredit $18 \%$. Hasil kesimpulan tersebut menunjukkan bahwa usaha peternakan sapi perah peternak Gapoktan Sumber Mulya dinyatakan layak secara finansial.
\end{abstract}

Kata kunci: Analisis finansial, anggota peternak, sapi perah.

\section{Pendahuluan}

Usaha peternakan sapi perah rakyat merupakan salah satu sektor usaha yang banyak memberi manfaat dalam memenuhi kebutuhan pangan yang terus meningkat dan penciptaan lapangan kerja serta dijalankan peternak secara teratur terus menerus pada suatu tempat dan dalam jangka waktu tertentu,dan skala kepemilikan sapi perah relatif kecil $(<3)$ ekor laktasi, untuk tujuan komersial yang menghasilkan susu dan mendapatkan penghasilan harian (Sundari dan Katamso, 2010). Negara Indonesia adalah salah satu negara yang memiliki kegiatan agribisnis sapi perah rakyat terbesar di kawasan Asia Tenggara. Dalam hal tersebut menurut Setiyawan et al. (2005) mengemukakan bahwa industri susu nasional baru bisa memenuhi kebutuhan susu dalam negeri sebesar 39\% dari permintaan konsumsi susu nasional, serta sisanya sebesar $61 \%$ berasal dari impor. Kondisi tersebut memperlihatkan bahwa potensi yang ada di dalam suatu usaha peternakan sapi perah rakyat belum sepenuhnya dimanfaatkan secara optimal guna memenuhi kebutuhan susu dalam negeri (Makin, 2011).

Kabupaten Kepahiang adalah salah satu wilayah di Propinsi Bengkulu yang cocok untuk pengembangan peternakan sapi perah rakyat. Pengembangan peternakan sapi perah rakyat tersebut dimulai sejak tahun 2008, tepatnya pada Gabungan kelompok tani (Gapoktan) Sumber Mulya di Desa Sukasari Kecamatan Kabawetan. Gapoktan Sumber Mulya berdiri sejak tahun 2008 dengan anggota sebanyak 40 orang kepala keluarga dengan jumlah sapi perah siap bunting sebanyak 80 ekor. Sapi perah merupakan komoditi unggulan yang 
dikembangkan pemerintah daerah di Desa Sukasari tepatnya di kelompok ternak Sumber Mulya. Tujuan pengembangan sapi perah pada kelompok peternak tersebut di Kabupaten Kepahiang adalah untuk mengasilkan susu segar guna memenuhi kebutuhan masyarakat, penciptaan lapangan kerja, dan pemanfaatan sumber daya alam terutama hijauan dan limbah pertaninan (sayuran) yang melimpah. Pengembangan peternakan sapi perah rakyat juga merupakan salah satu usaha yang diharapkan berkembang baik dan menguntungkan sehingga dapat dijadikan percontohan pada anggota masyarakat lainnya. Dilain fihak pengembangan usaha peternakan sapi perah tersebut, selama beberapa tahun dari tahun 2008 sampai sekarang terjadi penurunan , baik jumlah populasi ternak maupun jumlah peternak sapi perah yang menjalalankan usahanya sekitar sampai sekarang hanya 12 orang (BPS, 2018). Berdasarkan hal tersebut perlu dilakukan penelitian mengenai analiis finansialnya pada usaha peternakan sapi perah rakyat.

Peningkatan untuk skala optimalisasi potensi usaha peternakan rakyat dapat diketahui antara lain, melalui analisis finansial usaha dengan cara mengevaluasi investasi-investasi yang ditanamkan, biaya-biaya produksi, dan penerimaan atas penjualan produk usaha peternakan sapi perah rakyat (Setiyawan et al.2005; Budiharjo dan Prasetyo, 2012). Aspek finansial menitikberatkan terutama perbandingan antara biaya dan revenue earnings proyek yang meliputi ; solusi proyek tersebut akan terjamin dananya untuk dipertahankan; bagaimana proyek mampu membayar kembali dana tersebut; dan apakah proyek tersebut akan berkembang sehingga secara finansial dapat berdiri sendiri (Kadariah, 2001; Hadiwidjaya dan Lely, 2009). Beberapa cara perhitungan untuk menganalisis dari aspek finansial meliputi Return On Investment (ROI), Payback Period (PP), Net Present Value (NPV), Benefit Cost Ratio (BCR), dan Internal Rate of Return (IRR)

Return On Invesment (ROI) adalah cara.membandingkan antara keuntungan bersih diterima dengan investasi yang dikeluarkan. Sasaran pengembangan cara ROI adalah mengetahui besaran kentungan rata-rata yang dapat diperoleh sehubungan dengan investasi yang telah dikeluarkan (Riyanto, 2001; Setyawan, 2003). Payback Period (PP) adalah cara menghitungkan lamanya waktu untuk mengembalikan biaya investasi riil berdasarkan penerimaan yang nyata diterima setiap tahun (Setiyawan et al. 2005). Metode Net Present Value (NPV) merupakan cara yang menghargai uang sesuai dengan perubahan waktu yaitu mempertimbangkan nilai sekarang dari outlay dan proceed pada tingkat bunga kredit yang telah ditentukan dengan cara mengurangi present value outlay dari present value proceed (Riyanto, 2001). Untuk analisis NPV terlebih dahulu harus ditentukan tingkat suku bunga yang berlaku saat itu.

Benefit Cost Ratio (BC Ratio) adalah suatu cara membandingkan antara present value proceed dengan present value outlay pada tingkat bunga kredit yang telah ditentukan (Kadariah, 2001). BC Ratio tersebut dihitung sebagai cost yaitu biaya modal atau biaya investasi permulaan, biaya operasional dan biaya pemeliharaan, serta yang dihitung sebagai benefit adalah nilai total produksi (Riyanto,2001). Husnan dan Suwarsono (2000) mengemukakan bahwa sebelum menghitung $B C$ Ratio harus ditentukan terlebih dahul besaranya tingkat suku bunga diskonto, karena nilai $\mathrm{BC}$ Ratio sangat tergantung pada tingkat suku bunga yang berlaku.

Internal Rate Return (IRR) merupakan sebagai tingkat bunga usaha yang menjadikan jumlah nilai sekarang dari proceed sama dengan jumlah nilai sekarang dari biaya modal. Perhitungan IRR tersebut melalui cara cobacoba sampai ditemukan tingkat bunga yang dapat menjadikan present value proceed sama besar dengan present value outlay (Riyanto,2001). Kadarsih (2001) mengemukakan bahwa dalam perhitungan IRR harus dilakukan interpolasi antara discount rate tertinggi yang memberi NPV negatif sehingga diperoleh NPV sebesar nol.

Penelitian ini bertujuan untuk mengetahui tingkat kelayakan usaha peternakan sapi perah peternak Gapoktan Sumber Mulya pada tingkat aspek finansial. Hasil penelitian tersebut diharapkan dapat memberikan informasi mengenai potensi keuangan sebenarnya yang dimiliki usaha peternakan sapi perah peternak 
Gapoktan Sumber Mulya dimasa yang akan datang. Manfaat lain yaitu memberikan pengetahuan tentang cara-cara mengetahui tingkat kelayakan usaha peternakan sapi perah rakyat terutama pada aspek finansialnya.

\section{Bahan dan Metode}

Materi penelitian digunakan untuk penelitian ini adalah peternak Gapoktan Sumber Mulya yang berlokasi di Kecamatan Kabawetan Kabupaten Kepahiang. Penelitian ini telah dilakukan pada bulan Juli - Agustus 2018. Pelaksanaan penelitian dilakukan dengan pengamatan terhadap objek secara langsung di lapangan dan wawancara dengan bantuan kuesioner untuk mendapatkan data yang diperlukan dengan metode survei. Berdasarkan dari lokasi yang telah ditentukan kemudian dilanjutkan pengambilan sampel responden secara purposive sampling yaitu peternak yang tergabung pada Gapoktan Sumber Mulya. Jumlah peternak sapi perah di lokasi penelitian selurhnya sebanyak 12 peternak.

Data dikumpulkan meliputi data primer dan sekunder. Data primer yaitu data diperoleh langsung dari responden melalui kuisioner dan wawancara, meliputi banyaknya pemberian pakan, biaya pembuatan kandang, data kepemilikan ternak, biaya bibit, biaya tenaga kerja, harga jual pedet, dara, dan induk afkir. Data diperoleh dari peternak yang berkaitan dengan analisis usaha adalah data selama periode pemeliharaan selama 1 tahun yaitu dari bulan Juli 2017 - Juni 2018. Rentang waktu ini berfluktuasi harga sapronak dapat terwakili selama satu tahun produksi. Data sekunder meliputi data diperoleh dari instansi terkait yaitu data produksi susu dan jumlah peternak.

Analisis data dilakukan dengan metode deskriptif. Data yang diperoleh ditabulasi dan dihitung kemudian dianalisis dengan menggunakan kriteri dalam analisis finansial usaha yang meliputi Return On Invesment (ROI) (Riyanto, 2001). Payback Period (PP), Net Present Value (NPV) (Husnan dan Suwarsono, 2000). Benefit Cost Ratio (BC Ratio) dan Internal Rate Return (IRR) (Kadariah, 2001).

\section{Hasil dan Pembahasan}

Gambaran Usaha Peternakan Sapi Perah Peternak Gapoktan Sumber Mulya

Peternak sapi perah Gapoktan Sumber Mulya Kepahiang berada di desa Sukasari Kecamatan Kabawetan Kabupaten Kepahiang. Peternakan tersebut berada pada daerah ketinggian $\pm 800 \mathrm{~m}$ di atas permukaan laut (dpl). Kabupaten Kepahiang merupakan salah satu wilayah di provinsi Bengkulu yang cocok untuk pengembangan sapi perah. Secara georafis kabupaten Kepahiang merupakan daerah pegunungan yang memiliki suhu lingkungan dingin $\left(17-28{ }^{\circ} \mathrm{C}\right)$ dan memiliki kekayaan alam berupa pakan ternak, seperti rumput alam, limbah pertanian, dan limbah industri pertanian yang melimpah untuk pengembangan sapi perah. Pengembangan usaha peternakan sapi perah peternak Gapoktan Sumber Mulya Kepahiang dimulai sejak tahun 2008 tepatnya di Gapoktan Sumber Mulya di Desa Sukasari Kecamatan Kabawetan. Usaha peternakan sapi perah merupakan komoditi unggulan yang dikembangkan pemerintah daerah di Desa Sukasari tepatnya pada peternak Gapoktan Sumber Mulya. Tujuan pengembangan usaha peternakan sapi perah yang diharapkan berkembang baik dan menguntungkan sehingga dapat dijadikan percontohan pada anggota masyarakat lainnya. Kondisi topografi usaha peternakan sapi perah peternak Gapoktan Sumber Mulya tergolong ideal untuk pemeliharaan ternak sapi perah dengan. Kelembaban udara di peternakan sapi perah sekitar 50-90 persen. Rataan komposisi ternak pada usaha peternakan sapi perah peternak Gapoktan Sumber Mulya selama 1 tahun dari bulan Juli 2017 sampai dengan bulan Juni 2018 tertera pada Tabel 1.

Hasil penelitian yang tertera pada Tabel 1 . menunjukkan bahwa usaha peternakan yang dipelihara oleh peternak Gapoktan Sumber Mulya selama 12 bulan, dari bulan juli 2017 ke bulan Juni 2018 dengan perbandingan sapi perah laktasi dan kering (40\% VS $20 \%$ ) memperlihatkan kurang ideal, ,karena menurut pendapat Makin (2011) dan Suherman et al. (2013) yang ideal perbandingan sapi perah sedang laktasi dengan sapi perah kering yaitu $85 \%$ : $15 \%$.

Hasil pengamatan yang terlihat pada Tabel 2. memperlihatkan produksi susu per hari per ekor 
Tabel 1. Rataan komposisi usaha peternakan sapi perah peternak Gapoktan Sumber Mulya selama satu tahun terhitung dari bulan Juli 2017 sampai dengan bulan Juni 2018

\begin{tabular}{|c|c|c|c|}
\hline Nomor urut & Komposisi ternak & Jumlah (ekor) & Persentase (\%) \\
\hline \multirow[t]{3}{*}{1} & Pedet & & \\
\hline & Jantan & 1 & 20 \\
\hline & Betina & 1 & 20 \\
\hline \multirow[t]{3}{*}{2} & Induk & & \\
\hline & Laktasi & 2 & 40 \\
\hline & Kering & 1 & 20 \\
\hline \multirow[t]{2}{*}{3} & Pejantan & 0 & 0 \\
\hline & Total & 5 & 100 \\
\hline
\end{tabular}

Tabel 2. Rataan produksi susu pada usaha peternakan sapi perah peternak Gapoktan Sumber Mulya selama satu tahun terhitung dari bulan Juli 2017 sampai dengan bulan Juni 2018

\begin{tabular}{clr}
\hline No urut & \multicolumn{1}{c}{ Rataan } & \multicolumn{1}{c}{ Total } \\
\hline 1 & Jumlah Sapi Laktasi (ekor) & 3,00 \\
2 & Produksi Susu (liter/bulan) & 765,00 \\
3 & Prodksi Susu (liter/hari) & 25,50 \\
4 & Produksi Susu (liter/hari/ekor) & 8,50 \\
\hline
\end{tabular}

sebesar 8,50 liter. Hal tersebut tidak sesuai dengan hasil penelitian Setiyawan et al. (2005) dan Suherman (2013), yang menyatakan bahwa produksi susu sapi perah di Indonesia umumnya masih rendah, yaitu hasil susu rata-rata per ekor per hari sebanyak 10,50 liter dengan bangsa ternak Fries Holstein (FH). Namun hasil produksi susu peternakan sapi perah peternak Gapoktan Sumber Mulya masih rendah dibandingkan hasil penelitian Sundari dan Katamso (2010). Rendahnya produksi susu per hari per ekor pada peternakan sapi perah peternak Gapoktan Sumber Mulya diakibatkan pemberian pakan, baik hijauan maupun pakan tambahan (konsentrat) masih kurang dari kebutuhan pakan seekor sapi perah $\mathrm{FH}$, serta ditambah masih ada hasil produksi susu yaitu libur susu sehingga tidak laku untuk dipasarkan.

Produksi susu per ekor per hari pada peternakan sapi perah peternak Gapoktan Sumber Mulya lebih baik jika dibandingkan dengan penelitian yang dilakukan Herawati (2003) menyatakan bahwa produksi susu sapi perah per hari hanya 7,63 liter/ekor. Kadar lemak susu peternakan sapi perah anggota Gapoktan Sumber Mulya sebesar 3,00 dengan berat jenis 1,026. Hal ini sesuai dengan pendapat Soetarno (2000) bahwa kadar lemak susu tidak boleh kurang dari $2,7 \%$. Perbedaan besarnya kadar lemak dipengaruhi oleh bangsa sapi, sifat keturunan, umur sapi, bulan laktasi, kebuntingan, dan pakan (Makin, 2011).

Investasi

Investasi dilakukan pada usaha peternakan sapi perah peternak Gapoktan Sumber Mulya meliputi investasi ternak sapi perah, bangunan,, peralatan, kendaraan, instalasi air dan listrik, dan peralatan kandang. Jenis investasi secara lengkap tertera pada Tabel 3.

Hasil pengamatan dan analisis yang tertera pada Tabel 3 menunjukkan bahwa investasi ternak sapi perah merupakan investasi terbesar dari keseluruhan investasi. Hal tersebut menunjukkan bahwa kesediaan ternak merupakan investasi utama usaha peternakan sapi perah peternak Gapoktan Sumber Mulya dalam upaya proses produksi untuk menghasilkan susu. Berdasarkan hal tersebut, ketersediaan peternakan sapi perah merupakan modal utama dalam usaha mencari keuntungan. Pernyataan tersebut sesuai dengan pendapat Husnan dan Suwarsono (2000) yang menyatakan bahwa tujuan utama investasi adalah memperoleh berbagai manfaat yang layak dikemdian hari. Manfaat tersebut diantaranya penyerapan tenaga kerja keluarga, 
Tabel 3. Investasi usaha peternakan sapi perah peternak Gapoktan Sumber Mulya

\begin{tabular}{cccc}
\hline No & Jenis Investasi & Harga Pembelian (Rp) & Persentase (\%) \\
\hline 1 & Ternak & $60.000 .000,00$ & 53,87 \\
2 & $\begin{array}{c}\text { Bangunan } \\
\text { kandang }\end{array}$ & $40.000 .000,00$ & 35,91 \\
& Kendaraan motor & $8.000 .000,00$ & 7,18 \\
3 & Instalasi air & $1.200 .000,00$ & 1,07 \\
4 & Peralatan & $400.000,00$ & 0,36 \\
5 & Instalasi listrik & $900.000,00$ & 0,81 \\
7 & Peralatan kandang & $876.000,00$ & 0,79 \\
\hline & Jumlah Investasi & $111.376 .000,00$ & 100,00 \\
\hline
\end{tabular}

peningkatan output yang dihasilkan, penghematan, dan penambahan devisa.

\section{Biaya Produksi}

Biaya produksi pada usaha peternakan sapi perah peternak Gapoktan Sumber Mulya terdiri dari biaya tetap dan biaya variabel. Biaya tetap pada usaha peternakan sapi perah anggota Gapoktan Sumber Mulya meliputi biaya sewa tanah, penyusutan, biaya tenaga kerja, dan pajak bumi bangunan (PBB). Biaya penyusutan ternak, penyusutan bangunan, penyusutan peralatan, penyusutan kendaraan, penyusutan instalasi air dan listrik, serta peralatan kandang dihitung sebagai total biaya penyusutan per tahun. Sebagai biaya variabel adalah biaya pakan hijauan, biaya pakan konsentrat, biaya obat dan vaksin, biaya perbaikan dan perawatan, transportasi, biaya pemasaran, dan biaya lainnya. Total biaya produksi merupakan penjumlahan biaya tetap dan biaya variabel tetap merupakan biaya tidak tetap yang dikeluarkan oleh peternak sapi perah Gapoktan Sumber Mulya untuk.biaya transportasi pemasaran susu diberikan berdasarkan berapa banyak pemasaran tersebut berhasil mengirim susu kepada Tempat Penampungan Susu (TPS) atau koperasi, semakin banyak pemasaran tersebut berhasil menjual susu kepada TPS atau koperasi maka komisi yang didapat juga akan semakin banyak.

\section{Penerimaan}

Besarnya penerimaan peternakan sapi perah peternak Gapoktan Sumber Mulya per tahun dari penjualan susu, penjualan pedet, kotoran, karung bekas pakan konsentrat, dan nilai tambah ternak yang tertera pada Tabel 5 . selama setahun proses produksi (Suherman, 2006). Lebih jelas total biaya produksi peternakan sapi perah anggota Gapoktan Sumber Mulya tertera pada Tabel 4. berikut ini

Tabel 4. menunjukkan besarnya rataan biaya produksi pada peternakan sapi perah peternak Gapoktan Sumber Mulya selama 1 tahun yang terhitung dari bulan Juli tahun 2017 sampai dengan bulan Juni tahun 2018 sebesar Rp. $61.138 .760,00$. Rataan biaya produksi yang terbesar adalah biaya pakan sebesar $\mathrm{Rp}$. $39.040 .062,00(63,85 \%)$ dan gaji tenaga kerja keluarga sebesar Rp. 12.000.000,00 (19,63\%). Hal ini sesuai dengan pendapat Hadiwidjaya dan Lely. (2009) bahwa biaya pakan merupakan biaya terbesar dari keseluruhan biaya produksi. Listrik merupakan sarana penting dalam usaha peternakan sapi perah karena listrik merupakan sarana penerangan dan membantu untuk memperlancar kegiatan usaha peternakannya. Transportasi memasarkan susu dan gaji tidak

Hasil penelitian yang tersaji pada Tabel 5 . menunjukkan besarnya rataan peneriamaan peternakan sapi perah peternak Gapoktan Sumber Mulya yang terbesar berasal dari penjualan susu dan penjualan pedet. Rataan Penerimaan tergantung pada jumlah susu dijual melalui pemasaran yang dijual ke koperasi. Penerimaan terbesar berasal dari penjualan susu tersebut yang dilakukan pemasaran ke koperasi sebanyak 9.180 liter dengan besarmya penerimaan Rp. 70.800.009,00 (81,70\%) serta harga susu Rp. 6.000,00/liter. Penerimaan peternakan sapi perah peternak Gapoktan Sumber Mulya beasal dari penjualan pedet sebesar Rp.4.000.000,00/tahun (4,62\%), rataan penerimaan peternak dari penjualan kotoran sebesar Rp. 3.600.000,00 per tahun (4,16\%) dan penerimaan dari penjualan karung berkas 
Tabel 4. Total Biaya Produksi Peternakan Sapi Perah Peternak Gapoktan Sumber Mulya selama Setahun Terhitung dari Bulan Juli 2017 sampai dengan Bulan Juni 2018

\begin{tabular}{llrl}
\hline Biaya Produksi & Komponen Biaya & Jumlah (Rp) & Persentase (\%) \\
\hline A. Biaya Tetap & Penyusutan Kandang & $1.500 .000,00$ & 2,45 \\
& PenyusutanKamar Susu & $200.000,00$ & 0,33 \\
& Penyusutan bangunan & $700.000,00$ & 1,14 \\
& Penyusutan Kendaraan & $400.000,00$ & 0,65 \\
& Penyusutan Peralatan & $160.000,00$ & 0,26 \\
& Gaji tenaga kerja keluarga & $12.000 .000,00$ & 19,63 \\
Total Biaya Tetap & Sewa tanah & $50.000,00$ & 0.08 \\
B. Biaya Variabel & & $15.010 .000,00$ & 24,55 \\
& Pakan & & 63,85 \\
& Perbaikan & $39.040 .062,00$ & 1,41 \\
& Kesehatan Hewan dan IB & $860.000,00$ & 0,62 \\
& & $377.082,00$ & 3,21 \\
& Bahan Bakar & & 0,39 \\
& Listrik & $1.961 .616,00$ & 5,89 \\
\hline Total Biaya Variabel & Transfortasi pemasaran & $3.600 .000,00$ & 0,39 \\
\hline & Lain-lain & $240.000,00$ & 75,45 \\
\hline
\end{tabular}

konsentrat sebesar Rp. 2.160.000,00/tahun $(2,49 \%)$. Hal tersebut merupakan cara yang dilakukan peternakan sapi perah peternak Gapoktan Sumber Mulya untuk menambah penerimaan sehingga mempengaruhi keuntungan dan pendapatannya.

Pendapatan

Pendapatan usaha peternakan sapi perah peternak Gapoktan Sumber Mulya diperoleh total penerimaan dikurang total biaya. Pendapatan tersebut merupakan laba sebelum pajak yang apabila dikurangi pajak pendapatan menghasilkan laba bersih setelah pajak. Pendapatan atau laba usaha peternakan sapi perah peternak Gapoktan Sumber Mulya merupakan selisih dari biaya yang dikeluarkan dengan penerimaan yang diperoleh dari kegiatan produksi. Besar kecilnya pendapatan tergantung dari penerimaan dan biaya yang dikeluarkan selama proses produksi yang teretera pada Tabel 6 .

Tabel 6. menunjukkan bahwa rataan pendapatan atau laba (keuntungan) usaha peternakan sapi perah peternak Gapoktan Sumber Mulya per tahun sebesar Rp. 25.421.240,00 yang diperoleh dari total penerimaan sebesar Rp 86.560.000,00 dikurangi total biaya sebesar Rp. 61.138.760. Hasil perhitungan besarnya nilai rataan profitabilitas pada usaha peternakan sapi perah peternak Gapoktan Sumber Mulya sebesar 41,58 \%. Nilai profitabilitas $41,58 \%$ lebih besar dari tingkat suku bunga kredit usahatani, baik BRI maupn BNI dan Mandiri periode Juni 2018 yaitu sebesar $11,00 \%$. Suku bunga yang digunakan dalam perhitngan ini bukan suku bunga deposito melainkan suku bunga kredit usahatani dikarenakan usaha peternakan sapi perah peternak Gapoktan Sumber Mulya mnggunakan modal yang berasal dari kredit usahatani dalam usahanya. Berdasarkan perhitungan menunjukkan bahwa nilai profitabilitas usaha peternakan sapi perah peternak Gapoktan Sumber Mulya berbeda dengan nilai suku bunga kredit usahatani dari bank yang berlaku, sehingga usaha peternakan sapi perah peternak Gapoktan Sumber Mulya ini profitable, hal ini sesai hasil penelitian Hadiwidjaya dan Lely (2009), Sundari dan Katamso (2010), dan Wardani et al. (2012) bahwa semakin besar tingkat keuntungan menunjukkan semakin baik manajemen dalam mengelola usahanya. 
Tabel 5. Penerimaan dari peternakan sapi perah peternak Gapoktan Sumber Mulya dari bulan Juli 2017 sampai dengan bulan Juni 2018

\begin{tabular}{clccc}
\hline No & Sumber Penerimaan & Jumlah Produksi & Penerimaan (Rp) & Persentase (\%) \\
\hline 1 & Susu (liter) & $9.180,00$ & $70.800 .000,00$ & 81,79 \\
2 & Kotoran (kg) & $72.000,00$ & $3.600 .000,00$ & 4,16 \\
3 & Pedet (ekor) & 1,00 & $4.000 .000,00$ & 4,62 \\
4 & Pertambahan Nilai Ternak & 4,00 & $6.000 .000,00$ & 6,93 \\
& (ekor) & & \\
5 & Karung bekas konsentrat & $4.320,00$ & $2.160 .000,00$ & 2,49 \\
& (buah) & & \\
\hline & Jumlah Penrimaan & $86.560 .000,00$ & 100,00 \\
\hline
\end{tabular}

Tabel 6. Pendapatan peternak sapi perah Gapoktan Sumber Mulya selama setahun (terhitung dari bulan Juli 2017 sampai dengan bulan Juni 2018)

\begin{tabular}{lr}
\hline \multicolumn{1}{c}{ Pendapatan } & \multicolumn{1}{c}{ Jumlah (Rp) } \\
\hline Total penerimaan & $86.560 .000,00$ \\
Total biaya & $61.138 .760,00$ \\
Laba & $25.421 .240,00$ \\
Laba sebelum pajak & 0,00 \\
Laba bersih setelah pajak & $25.421 .240,00$ \\
\hline
\end{tabular}

Analisis Finansial Usaha

Analisis usaha peternakan sapi perah peternak Gapoktan Sumber Mulya menyangkut penilaian terutama mengenai perbandingan antara pengeluaran (outlay) dan pemasukan (proceed). Analisis finansial usaha peternakan sapi perah peternak Gapoktan Sumber Mulya tersebut menggunaan metode penilaian yang mmperhitungan nilai uang atas waktu. Metode digunakan dalam analisis ini adalah ROI, PP, NPV, BCRatio, dan IRR.

Rataan keuntungan bersih usaha peternakan sapi perah peternak Gapoktan Sumber Mulya sebesar Rp. 25.421.240,00, total keseluruhan investasi yang ditanamkan sebesar $\mathrm{Rp}$. 111.376.000,00. Hasil perhitungan diperoleh bahwa nilai ROI sebesar $22,82 \%$. Nilai ROI tersebut lebih besar daripada tingkat suku bunga deposito bank yang berlaku pada tahun 2018 sebesar $9 \%$ per tahun. Artinya usaha peternakan sapi perah peternak Gapoktan Sumber Mulya dinyatakan layak untuk beroperasi dalam melakukan kegiatan produksi.

Berdasarkan hasil perhitungan, diperoleh hasil PP peternakan sapi perah peternak Gapoktan Sumber Mulya adalah selama 4 tahun 5 bulan. Artinya investasi yang ditanamkan akan kembali dalam waktu 4 tahun 5 bulan. Payback Period (PP) tersebut tergolong pendek karena peternak menargetkan seluruh investasi akan kembali dalam waktu 10 tahun. Hasil perhitungan PP tersebut menunjukkan bahwa usaha peternakan sapi perah peternak Gapoktan Sumber Mulya dinyatakan layak untuk beroperasi. Hal ini sesuai dengan pendapat Husnan dan Suwarsono (2000) bahwa jika PP lebih pendek daripada jangka waktu yang telah diterapkan maka proyek dikatakan menguntungkan, bila PP lebih lama daripada jangka waktu yang diterapkan maka proyek ditolak atau dinyatakan tidak layak beroperasi.

Total nilai sekarang penerimaan kas bersih atau PV Proceed usaha peternakan sapi perah peternak Gapoktan Sumber Mulya sebesar Rp. $86.560 .000,00$, total nilai sekarang investasi atau PV Outlay sebesar Rp. 61.138.760,00. Selisih dari kedua nilai tersebut merupakan Net Present Value sebesar 25.421.240,00. Hasil perhitungan NPV tersebut bernilai positif, artinya benefit atau keuntungan yang diterima lebih besar daripada biaya yang dikeluarkan. Hal tersebut sesuai dengan pendapat Kadariah (2001), bahwa proyek yang menguntungkan adalah proyek yang mempunyai nilai NPV positif, tetapi proyek yang mempunyai NPV negatif adalah proyek yang tidak menguntungkan.

Total PV proceed usaha peternakan sapi perah peternak Gapoktan sebesar Rp. 86.560.000,00, sedang total PV Outlay sebesar Rp. 61.138.760,00. Hasil perhitungan diperoleh BC Ratio sebesar 1,42. Nilai tersebut menunjukkan bahwa usaha peternakan sapi perah peternak Gapoktan Sumber Mulya dinyatakan menguntungkan dan layak untuk beroperasi, karena mempunyai benefit atau 
penerimaan lebih besar daripada biaya yang dikeluarkan. Hal tersebut sesuai dengan pendapat Kadariah (2001) bahwa BC Ratio yang lebih besar daripada 1 maka usaha dinyatakan menguntungkan dan layak untuk beroperasi.

Tingkat bunga yang dicoba dalam penelitian ini sebesar $28 \%$ dan $29 \%$. NPV yang diperoleh dari hasil perhitungan dengan menggunakan tingkat bunga 28 \% sebesar Rp. 673.236,22, sedangkan NPV diperoleh dari perhitungan tingkat bunga 29 \% sebesar Rp736.599,30. Hasil perhitungan diperoleh nilai IRR sebesar 28,45\%. Artinya nilai sekarang investasi dan nilai sekarang penerimaan bersih akan sama besar daripada tingkat bunga $28,00 \%$. Hasil perhitungan tertsebut menunjukkan tingkat laba usaha lebih besar daripada tingkat bunga kredit bank yang berlaku tahun 2018 sebesar 18 $\%$. Berdasarkan hal tersebut, usaha peternakan sapi perah peternak Gapoktan Sumber Mulya dinyatakan layak untuk beroperasi. Hal tersebut sesuai dengan pernyataan Riyanto (2001) yang mengemukakan bahwa bila IRR lebih besar daripada tingkat bunga kredit yang berlaku berarti usaha layak untuk dijalankannya.

\section{Kesimpulan}

Berdasarkan hasil penelitian dan perhitungan dapat disimpulkan sebagai berikut : Nilai ROI sebesar 22,82 \%; PP sebesar 4 tahun 5 bulan; NPV sebesar RP. 25.421.240,00; BC Ratio sebesar 1,43; dan nilai IRR sebesar 28,45\%. Hasil perhitungan tersebut menunjukkan bahwa usaha peternakan sapi perah peternak Gapoktan Sumber Mulya dinyatakan layak secara finansial.

\section{Daftar Pustaka}

Badan Psat Statistik (BPS). 2018. Bengkl dalam angka 2018. Bengkulu.

Budiharjo dan Prasetyo. 2012. Analisis profitabilitas pada peternakan sapi perah "Karunia" Kediri. Animal Agricultural Journal. !(1) : 339 -357.

Hadiwidjaya, RD dan F.T. Lely. 2009. Pengaruh profitabilitas terhadap dividend payout ratio pada

perusahaan manufaktur di Indosia. Jurnal Organisasi dan Manajemen. 5(2) : 49-54.
Herawati. 2003. Pengaruh subtitusi hijauan pakan dalam ransum dengan nanas afkir terhadap produksi dan kualitas susu pada sapi perah laktasi. J.Indon.Trop.Anim.Agric.Vol : 28. Nomer 2. $56-63$.

Husnan dan Suwarsono.2000. Studi kelayakan proyek. Unit penerbit dan percetakan AMP YKPM. Jogyakarta

Kadariah. 2001. Evaluasi proyek analisis ekonomis. Lembaga Penerbit Fakultas Ekonomi Universitas Indonesia. Jakarta.

Makin M. 2011. Tatalaksana peternakan sapi perah. Graha Ilmu.Jogyakarta.

Riyanto, R. 2001. Dasar - dasar pembelanjaan perusahaan. Penerbit BPFE. Yogyakarta.

Setiyawan H, S.I Santoso, Mukson. 2005. Analisis finansial usaha peternakaqn sapi perah pada tingkat

perusahaann. Animal Production Journal 7 (1) : $40-45$.

Setyawan, H. 2003. Analisis finansial usaha sapi perah pada PT. Rumeksa Mckaring Sabda Kecamatan

Agromlyo Kabupaten Salatiga. Laporan ilmiah. Fakultas Peternakan Universitas Diponegoro. Semarang.

Soetarno Y. 2000. Ilmu produksi ternaqk perah. Universitas Gadjahmada. Yogyakarta.

Suherman, D. 2006. Pendapatan dan pencurahan tenaga kerja keluarga pada berbagai skala usaha

peternakan sapi potong rakyat di kecamatan Sukaraja Bengkulu Selatan. Jurnal Sain Peternakan Indonesia 1 (2) : $26-31$.

Suherman D, B.P. Purwanto, I.G. Permana, W. Manalu. 2013. Penentan suhu kritis atas pada sapi dara Fries

Holstein berdasarkan respon fisiologis dan manajemen pakan melalui Artificial neural network. Disertasi. Pasca sarjana Institut Pertanian Bogor. Bogor. 
Sundari dan Katamso. 2010. Analisis pendapatan peternak sapi perah lokal dan eks impor anggota koperasi warga Mulya di Kabupaten Sleman Yogyakarta. J. Caraka Tani XXV no : 1: 26-32

Sutrisno. 2000. Manajemen Keuangan. Penerbit Ekonosia. Yogyakarta.
Wardani TC, K Bdiharjo, E Prasetyo. 2012. Analisis profitabilitas pada peternakan sapi perah "Karunia"

Kediri. Animaql Agricultural Jornal 1(1): 339 357. 